\title{
COMPOUND WORDS IN DAWAN LANGUAGE
}

\author{
I Wayan Budiarta \\ Universitas Warmadewa \\ iw.budiarta@warmadewa.ac.id
}

\begin{abstract}
The purpose of this study is to find out the structure of compound words and the types of compound words in Dawan language. This study belongs to qualitative research aiming at describing the structure and the types of compound words in Dawan language. The data are taken from language consultants (informants) of Dawan language speakers through interview method The result of analysis showed that compound words in Dawan language are structured by combining two different words whether the words in the same category or different category. The structure of compound words are built by combining noun $(\mathrm{N})$ with noun $(\mathrm{N})$, for instance mais-oni 'sugar' which is built by the noun mais 'salt' and the noun oni 'sweet'; noun (N) with verb (V), for instance bife-anaot 'prostitute' which is built by the noun bife 'woman' and the verb anaot 'work'; verb (V) with noun (N), for instance poni-haano 'propose' which is built by the verb poni 'hang' and the noun hauno 'leaf'; verb (V) with verb (V), for instance fua-tulu 'worship' which is built by the verb fua 'see' and the verb tulu 'give'; and noun (N) with adjective (Adj), for instance ume-kbubu 'kitchen' which is built by the noun ume 'house' and the adjective kbubu 'circle'. Further analysis on the compound words showed that they can also be classified into compound noun, compound verb, and compound adjective.
\end{abstract}

Keywords: compound words, compound noun, compound verb, compound adjective

\begin{abstract}
Abstrak
Tujuan dari kajian ini adalah untuk mengetahui struktur kata majemuk dan tipe kata majemuk yang terdapat dalam bahasa Dawan. Kajian ini digolongkan sebagai penelitian kualitatif karena bertujuan untuk mendeskripsikan secara kualitatif struktur dan tipe kata mejemuk dalam bahasa Dawan. Data penelitian ini diambil dari konsultan bahasa (informan) dari penutur bahasa Dawan. Dalam pengumpulan data, peneliti menyiapkan daftar tanyaan dan mengaplikasikan metode wawancara. Hasil analisis data menunjukkan bahwa kata mejemuk bahasa Dawan dibentuk dengan menggabungkan dua kata, baik dalam kategori kata yang sama maupun kategori kata yang berbeda. Struktur kata majemuk dibangun dengan menggabungkan nomina $(\mathrm{N})$ dengan nomina $(\mathrm{N})$, sebagai contoh maisoni 'gula' yang dibangun oleh nomina mais 'garam' dan nomina oni 'manis'; nomina (N) dengan verb (V), sebagai contoh bife-anaot'pelacur' yang dibangun oleh nomina bife 'wanita' dan verba anaot 'bekerja'; verba (V) dengan nomian $(\mathrm{N})$, sebagai contoh + poni-haano 'melamar' yang dibangun oleh verb poni 'gantung' dan nomina hauno 'daun'; verba (V) dengan verba (V), sebagai contoh fua-tulu 'memuja' yang dibangun oleh verba fua 'lihat' dan verba tulu 'beri'; dan nomina (N) dengan adjektiva (Adj), sebagai contoh ume-kbubu 'dapur' yang dibangun oleh nomina ume rumah' dan adjektiva kbubu 'lingkaran'. Analisis lebih lanju tterhadap struktur kata majemuk tersebut menunjukkan bahwa kata majemuk tersebut dapat diklasifikasikan menjadi kompositum nomina, kompositum verba, dan kompositum adjektiva.
\end{abstract}

Kata Kunci: kata mejemuk, kompositum nomina, kompositum verba, kompositum adjektiva

\section{INTRODUCTION}

Timor Islandis recognized as the place which has many local languages. Some of those local languages include Dawan language, Tetun language, Sabu language, Roti language, Bunak language,
Helong language, and Kemak language. Among those languages that live in Timor island, Dawan language is identified as the language which is widely spread and spoken as it lives in four regencies, namely Belu Regency, North Central Timor Regency, 
South Central Timor Regency, and Kupang Regency. The data from Statistic Center of East Nusa Tenggara Province in 2000 showed that the speaker of Dawan language is around 900.000 (Budiarta, 2009). In daily life, it is used both oral and written. The oral use of it can be seen in formal or informal meeting. Besides, it is also used as the language at elementary school from the first grade to the third grade, traditional ceremony, and church. While, the use in written can be seen in the bible, song lyrics, and literature.

There were several research that have been undertaken on Dawan language which studied some aspect of that language. From those researches, it was found that Dawan language has a productive metathesis as a special characterization. Referring to the special characterization, some linguists stated their argumentation on metathesis. Sanga (1989) stated that metathesis in Dawan language is really productive and arbitrary too as it only used to soften the sound. Tarno et al. (1992) stated that metathesis happened if the sound of the first and the second syllabic are different. From those two statements, it can be concluded that metathesis is the process of arbitrary voice adjustment which does not influence the function, role, and the meaning.

Besides those special characterization described above, there are other interesting linguistic aspects of Dawan language that can be undertaken into a research. One of those interesting aspects is morphology as it observes the word formation which includes the ways new words are coined in the languages of the world, and the way of forming of words are varied depending on how they are used in sentences. Word formation consists of affixation, compounding, reduplication, conversion, blending, clipping, borrowing, acronym, and backformation.

Derivation or word formation is not the only way of forming new words, of course. Many languages also form words by a process called compounding. Compounds are words that are composed of two (or more) bases, roots, or stems. In English we generally use free bases to compose compounds. Compounding or compound words are word formation process that forms new words which derives from two or more independent words. The words that are parts of the compound can be free morphemes (Fromkim and Rodman 1998:83). Sometimes, we assume that we know the word though we do not know what the word means. If we do not know the meaning of that word we cannot analyze the function of the word. The information about the word will be stored in our mental dictionary which includes information on its pronunciation (phonological, its meaning (semantic), and its syntactic class or category and specification.

Surprisingly, it's not that simple to settle a single criterion that works in all cases to identify compound words. Identifying compounds that is fairly reliable is 
that by testing whether a sequence of bases is a compound by seeing if a modifying word can be inserted between the two bases and still have the sequence make sense. If a modifying word cannot sensibly be inserted, the sequence of two words is a compound. In English, this test confirms that both apple pie and apple cake are compounds, in spite of their differing stress. In neither case can we insert a modifier like delicious between the two stems; *apple delicious pie and *apple delicious cake are equally peculiar (Katamba, 1997).

This study on compound words in Dawan language will try to discover how the word formation in Dawan language es- pecially through compounding is built which includes the recognition of the structure of the compound words and also what type do the compound words found in Dawan language based on the theory applied in this study.

\section{CONCEPTS AND THEORETICAL FRAMEWORK}

\section{CONCEPTS}

\section{Concept of Word Class}

In English, the form of compound can be classified in several ways, such as word class or semantic relation of its components. The following is the table of word class of compound words in English.

Table 1 English Compound Words

\begin{tabular}{|c|c|c|}
\hline MODIFIER & HEAD & COMPOUND \\
\hline Noun & Noun & Football \\
\hline Adjective & Noun & Blackboard \\
\hline Verb & Noun & Breakwater \\
\hline Preposition & Noun & Underworld \\
\hline Noun & Adjective & Blue-green \\
\hline Adjective & Adjective & Tumbledown \\
\hline Verb & Adjective & Over-ripe \\
\hline Preposition & Adjective & Browbeat \\
\hline Noun & Verb & Highlight \\
\hline Adjective & Verb & Freeze-dry \\
\hline Verb & Verb & Undercut \\
\hline Preposition & Verb & Love-in \\
\hline Noun & Preposition & Forthwith \\
\hline Adjective & Preposition & Takeout \\
\hline Verb & Preposition & \\
\hline Preposition & Preposition & \\
\hline
\end{tabular}

\section{Concept of Compound}

There were many concepts or definitions of compound given by some linguists. Haspelmath (2002: 85) who stated that compound is a complex lexeme that can be thought of as consisting oftwo or more base lexemes. In the simplest case, a compound consists of twolexemes that are joined together. Other concept of compound derived from Booij (2005: 93) who stated that compound is a combination of two lexemes or more. The concepts of 
compound is also came from Lieber (2009: 45) that claimed compounds are words that are composed of two (or more) bases, roots, or stems. From those concepts given by the linguists, it can be concluded that compound is a kind of word formation process in which two or more lexeme are combined to create a new word.

\section{THEORETICAL FRAMEWORK}

The production of compound words refers to the process of combining two words or more of the 60000 basic words that exist in the native speaker's mental dictionary. It is governed by a set of rules in which each of the two words in the process is called as a root of a certain lexical category such as noun, adjectives, verbs, or preposition. The recognition of a compound word is different from a phrase. The first rule to differentiate the identification between them is by distinguishing their phonological properties. A compound noun is pronounced with a primary stress and the first root, while all lexical words receive a primary stress in a noun phrase. The second rule to differentiate the identification between two is by distinguishing their syntactic properties. A compound word is not an interruptible unit, while a phrase can be interrupted to make it smaller or bigger (Carstairs-McCarthy, 2002: 59).

\section{Types of Compound Words}

According to Carstairs-McCarthy $(2002,59-63)$ types of compound word is divided into three, they are compound noun or commonly said as noun head word, compound verb or commonly said as verb head word, and compound adjective or commonly said as adjective head word. For instance, in English, compound word can be found in all major lexical categories. The major lexical categories include noun, verb, adjective, and preposition. These major lexical categories are combined to form compound word. The explanation of those compounds in English are described below

\section{Compound Noun/Noun Head Word}

A noun head word is a process of a compound production by adding a noun or adjective lexical categories in front of a noun lexical category. The process results in a new word which is called a noun compound word.

A. Noun + Noun
a. fire + engine $=$ fire engine
b. arm + chair = armchair
c. hand + bag $=$ handbag
d. body + guard = bodyguard
e. school + boy $=$ schoolboy
f. girl + friend $=$ girlfriend
g. night + guard $=$ night guard
h. text + book $=$ textbook
i. hand + book $=$ handbook
j. history + book $=$ history book

B. Adjective + Noun
a. white + house $=$ white house
b. green + house $=$ green house
c. blue + bird $=$ bluebird
d. black + sheep $=$ black sheep 

e. blue + collar $=$ blue-collar
f. white + collar $=$ white-collar
g. $\quad$ red + head $=$ redhead
h. white + people $=$ white people
i. black + people $=$ black people
j. black + market $=$ black-market
C. Verb + Noun
a. jump + suite $=$ jumpsuit
b. pick + pocket $=$ pickpocket
c. dare + devil $=$ daredevil
d. run + way $=$ runway
e. kick + boxer $=$ kick boxer

D. Preposition + Noun
a. after + thought $=$ afterthought
b. in + laws $=$ in-laws
c. up + grade $=$ upgrade
d. under + graduate $=$ undergraduate
e. down + grade $=$ downgrade
f. up + town $=$ uptown
g. down + town $=$ downtown
h. on + time $=$ on time
i. $\quad$ in + time $=$ in time
j. $\quad$ over + night $=$ overnight

\section{Compound Verb/Verb Head Word}

Compound verb or verb head word is a process of a compound verb production by adding a noun, or adjective, or preposition, or verb class or lexical category in front of a verb lexical category. The process result in a new word which is called a verb compound word. The following examples illustrate the compound verb found in English.

A. Noun + Verb

a. spoon + feed $=$ spoonfeed b. steam + roll $=$ steamroll

c. baby + sit $=$ babysit

d. brain + wash $=$ brainwash

e. house + keep $=$ housekeep

f. book + keep $=$ book keep

B. Adjective + Verb

a. white + wash $=$ whitewash

b. dry + clean $=$ dryclean

c. sweet + talk $=$ sweet talk

d. hard + work $=$ hard work

e. tumble + down $=$ tumbledown

f. white + wash $=$ whitewash

g. black + list $=$ blacklist

h. free + talk $=$ free-talk

i. $\quad$ clear + cut $=$ clear cut

j. $\quad$ long + forgotten $=$ long forgoten

C. Preposition + Verb

a. over + look $=$ overlook

b. over + estimate $=$ overestimate

c. over + come $=$ overcome

d. over + do $=$ overdo

e. over + take $=$ overtake

f. out + look $=$ outlook

g. out + put $=$ output

h. in + put $=$ input

i. $\quad$ under + estimate $=$ underestimate

j. $\quad$ under + go $=$ undergo

D. Verb + Verb
a. drop + kick $=$ dropkick
b. break + dance $=$ breakdance
c. dive + bomb $=$ divebomb

\section{Compound Adjective/Adjective Head Word}

An adjective head word is a process of a compound adjective production by 
adding a noun, or adjective, or preposition in front of adjective lexical category. This process will create a new word which is a called adjective compound word.

A. Noun + Adjective
a. nation + wide $=$ nationwide
b. sky + blue $=$ skyblue
c. navy + blue $=$ navy blue
d. razor + sharp $=$ razorsharp
e. blade + sharp $=$ bladesharp
f. ice + cold $=$ icecold
g. car + sick $=$ carsick
h. sea + sick $=$ seasick
i. air + sick $=$ airsick
j. ox + eyed $=$ oxeyed
B. Adjective + Adjective
a. red + hot $=$ redhot
b. deep + blue $=$ deepblue
c. dark + brown $=$ dark brown
d. light + brown $=$ light brown
e. dark + blue $=$ dark blue
f. light + blue $=$ light blue
g. blue + green $=$ blue green
h. light + yellow $=$ light yellow
i. metallic + green $=$ metallicgreen
j. south west $=$ southwest
C. Preposition + Adjective
a. over + ripe $=$ overripe
b. in + grown $=$ ingrown
c. near + sighted $=$ nearsighted
d. off + white $=$ offwhite

\section{Compound Preposition/Preposition Head Word}

A preposition head word is a process of a compound preposition production by adding a preposition in front of a preposition lexical category. The process result a new word which is called a preposition compound word.
a. in + to $=$ into
b. through + out $=$ throughout

Based on the explanation above, it can be concludes that compounding or compound words are the combination of two words in order to get a new word or a new meaning.

\section{DISCUSSION}

\section{THE STRUCTURE OF COMPOUND WORDS IN DAWAN LANGUAGE}

The result of analysis shows that the structure of compound words in Dawan language are built by combining noun $(\mathrm{N})$ with noun $(\mathrm{N})$, noun $(\mathrm{N})$ with verb $(\mathrm{V})$, verb $(V)$ with noun $(N)$, verb $(V)$ with verb $(\mathrm{V})$, and noun $(\mathrm{N})$ with adjective (Adj). The discussion in details of each combination of the structure of compound words will be described in the following.

\section{Noun with Noun Combination}

These types of compound words are built by combining noun with noun to form compound words. The result of combining noun with noun forms compound words which create new words and carry new meaning automatically. The combination of noun with noun which forms compound words in Dawan Language can be seen in the following table. 
Table 2 Noun and Noun Combination

\begin{tabular}{|c|c|c|c|}
\hline NO & $\mathbf{N}+\mathbf{N}$ & Compound Word & New Meaning \\
\hline 1 & $\begin{array}{l}\text { aheut + susu } \\
\text { 'picker' + 'milk' }\end{array}$ & aheut-susu & 'the youngest child' \\
\hline 2 & $\begin{array}{l}\text { mais }+ \text { oni } \\
\text { 'salt' +'sweet' }\end{array}$ & mais-oni & ‘sugar’ \\
\hline 3 & $\begin{array}{l}\text { 'nui' + 'nakaf } \\
\text { 'bone' + 'head' }\end{array}$ & nui-nakaf & 'skull/cranium' \\
\hline 4 & $\begin{array}{l}\text { mat + lanan } \\
\text { 'eye' + 'road' }\end{array}$ & mat-lanan & 'pioneer' \\
\hline 5 & $\begin{array}{l}\text { uis + neon } \\
\text { 'god' + 'day' }\end{array}$ & uis-neon & god \\
\hline 6 & $\begin{array}{l}\text { neno + anan } \\
\text { 'day' + 'child' }\end{array}$ & neno-anan & ‘yes’ \\
\hline 7 & $\begin{array}{l}\text { sabui + ai } \\
\text { 'ant' + 'fire' }\end{array}$ & sabui-ai & 'ant' \\
\hline 8 & $\begin{array}{l}\text { ot + kolo } \\
\text { 'car' + 'bird' }\end{array}$ & ot-kolo & 'airplane' \\
\hline
\end{tabular}

The examples (1) - (8) in the table above indicated that the compounds words in Dawan language are formed by combining noun with other noun. Each noun which constructs the compounds word above has their own meaning which are different from one another. One of the words has the function as a head and another as a modifier that that modifies the head. The combination creates a new nominal compound word and also carries a new meaning. In example (1), the compound word is built by combining the noun aheut 'picker' as the head and the noun susu 'milk' as the modifier resulting a compound word aheut-susu which carries a new meaning 'the youngest child'; in example (2), the compound word mais-oni 'sugar' is built by the noun mais 'salt' as the modifier and the noun oni 'sweet' as the head ; in example (3), the compound word nui-nakaf 'skull' is constructed by combining the noun nui 'bone' as the modifier and the noun nakaf 'head' as the head; in example (4), the compound word mat-lanan 'pioneer' is built by joining the noun mat 'eye' as the modifier and the noun lanan 'road' as the head. The same process of constructing compound words also happened in examples (5) - (8) which are built by combining one noun with other noun and also create new words and new meaning

\section{Noun with Verb Combination}

These types of compound words are constructed by joining noun with verb to form compound word in Dawan language. The result of joining noun with verb forms compound words which create new words and carry new meanings automatically. The combination of noun with verb which forms compound words in Dawan language can be seen in following table. 
Table 3 Noun and Verb Combination

\begin{tabular}{|c|c|c|c|}
\hline No & $\mathbf{N}+\mathbf{V}$ & Compound Word & New Meaning \\
\hline 1. & $\begin{array}{l}\text { lan + lefit } \\
\text { 'road' + 'cut' }\end{array}$ & lan-lefit & 'shortcut' \\
\hline 2. & $\begin{array}{l}\text { bife + anaot } \\
\text { 'woman' + 'work' }\end{array}$ & bife-anaot & 'prostitute' \\
\hline 3. & $\begin{array}{l}\text { ume + hana } \\
\text { 'house' + 'cook' }\end{array}$ & ume-hana & 'kitchen' \\
\hline 4. & $\begin{array}{l}\text { oe + hani } \\
\text { 'water' + 'dig' }\end{array}$ & ne-hani & 'well' \\
\hline 5. & $\begin{array}{l}\text { niut + sae } \\
\text { 'devil' + 'climd' }\end{array}$ & niut-sae & 'possessed by the devil' \\
\hline 6. & $\begin{array}{l}\text { fua + mnutu } \\
\text { 'bean' + 'slice' }\end{array}$ & fua-mnutu & 'mung bean' \\
\hline 7. & $\begin{array}{l}\text { funun + toen } \\
\text { 'hair' + 'pass' }\end{array}$ & funun-toen & 'eyebrow' \\
\hline 8. & $\begin{array}{l}\text { manas + nmof } \\
\text { 'sun' + 'fall' }\end{array}$ & manas-mnof & 'sunsets \\
\hline
\end{tabular}

The examples $(1)-(8)$ in the table above exhibit the compound words which are formed by combining two different elements of word. One is noun and another word is verb. Each of the word carry its own meaning. But when they are combined, they formed a new nominal category of word and a new meaning. In example (1), the compound word is built by combining the noun lan 'road' as the modifier and the verb lefit 'cut' as the head resulting a compound word lan-lefit 'shortcut'; in example (2), the compound word bife-anaot 'prostitute' is built by the noun bife 'woman' as the modifier and the verb anaot 'work' as the head; in example (3), the compound word ume-hana 'kitchen' is built by the noun ume 'house' as the modifier and the verb hana 'cook' as the head; in example (4), the compound word oehani 'well' is built by the noun oe 'water' as the modifier and the verb hani 'dig' as the head. Moreover, examples (5) - (8) also exhibit the same process of constructing compound words which are built by combining a noun with a verb.

\section{Verb and Noun Combination}

In this type, the compound words are constructed by combining verb with noun to form compound words. The result of combining verb with noun creates new words and carries new meaning automatically. Look at the following examples.

Table 4 Verb with Noun Combination

\begin{tabular}{|c|l|c|c|}
\hline No & \multicolumn{1}{|c|}{$\mathbf{V}+\mathbf{N}$} & Compound Word & New Meaning \\
\hline 1. & $\begin{array}{l}\text { fison + fanu } \\
\text { 'hit' + 'problem' }\end{array}$ & lison-fanu & 'speak' \\
\hline 2. & $\begin{array}{l}\text { tel + oe } \\
\text { 'draw' +'water' }\end{array}$ & poni-hauno & 'propose' \\
\hline 3. & $\begin{array}{l}\text { poni + hauno } \\
\text { 'hang' +'leaf' }\end{array}$ & san-tuaf & 'devil' \\
\hline 4. & $\begin{array}{l}\text { san + tuaf } \\
\text { 'see' + 'owned' }\end{array}$ & nakua-a'an & 'speak' \\
\hline 5. & $\begin{array}{l}\text { nakua + a'an } \\
\text { 'collapse' +'news' }\end{array}$ & $\begin{array}{l}\text { tel-hae } \\
\text { 'brake' + 'foot' }\end{array}$ & 'sandals \\
\hline 6.
\end{tabular}


RETORIKA: Jurnal Ilmu Bahasa, Vol. 2, No.1 April 2016, 9

\begin{tabular}{|c|l|c|c|}
\hline 7. & $\begin{array}{l}\text { ahake + neon } \\
\text { 'find' + 'day' }\end{array}$ & ahake-neon & 'angel' \\
\hline 8. & $\begin{array}{l}\text { op + enaf } \\
\text { 'walk' + 'mother' }\end{array}$ & op-enaf & 'road way' \\
\hline 9. & $\begin{array}{l}\text { asoi + sanat } \\
\text { 'fee' + 'problem' }\end{array}$ & asoi-sanat & 'redeemer' \\
\hline
\end{tabular}

The example (1) - (9) of compound words above are formed by combining two different elements of word, they are verb and noun. Each of the word carry its own meaning. But when they are combined, they formed a new nominal category of word and a new meaning. Compound noun in example (1), is built by combining the verb fison 'hit' as the modifier and the noun fanu 'problem' as the head resulting a compound word fison-fanu 'speak'; in example (2), the compound word tel-oe 'dragon fly' is filled by the verb tel 'draw' as the modifier and the noun oe 'water' as the head; in example (3), the compound word poni-haano 'propose' is constructed by the verb poni 'hang' as the modifier and the noun hauno 'leaf' as the head; in example (4), the compound word san-tuaf 'devil' is built by the verb san 'see' as the modifier and the noun tuaf 'owned' as the head. The same process of constructing compound words also appear in example (5) - (9) which are built by combining a verb with a noun.

\section{Verb and Verb Combination}

These kinds of compound words are built by combining verb with verb to form compound words. The result of combining verb with verb creates new words and carries new meaning automatically. Look at the following combination of verb with verb which forms compound words in Dawan language.

Table 5 Verb and Verb Combination

\begin{tabular}{|c|l|l|l|}
\hline No & \multicolumn{1}{|c|}{$\mathbf{V}+\mathbf{V}$} & Compound Word & \multicolumn{1}{|c|}{ New Meaning } \\
\hline 1. & $\begin{array}{l}\text { pete + kloe } \\
\text { 'dumpen' +cook' }\end{array}$ & pete-kloe & 'soaking wet' \\
\hline 2. & $\begin{array}{l}\text { tun + tauk } \\
\text { 'burn' +'watch' }\end{array}$ & fun-tauk & 'watch over' \\
\hline 3. & $\begin{array}{l}\text { fua + tulu } \\
\text { 'see' + 'give' }\end{array}$ & aka-nama & 'worship' \\
\hline 4. & $\begin{array}{l}\text { aka' + nama } \\
\text { 'say' + 'creep' }\end{array}$ & tupan-fin & 'crawl' \\
\hline 5. & $\begin{array}{l}\text { tupan + fin } \\
\text { 'sleep' +'through' }\end{array}$ & pan-bu'u & 'snail' \\
\hline 6. & $\begin{array}{l}\text { pan + bu'u } \\
\text { 'roast' +'accuse' }\end{array}$ & & \\
\hline
\end{tabular}

The compound words (1) - (6) above are formed by combining two verbs. Each of the verb carry its own meaning. But when they are combined, they formed a new nominal category of word and a new meaning. In example (1), the compound word is constructed by combining the verb pete 'dumpen' as the modifier and the verb 
kloe 'cook' as the head resulting a compound word pete-kloe 'soaking wet'; in example (2), the compound word tun-tauk 'watch over' is built by the verb tun 'burn' as the modifier and the verb tauk 'watch' as the head ; in example (3), the compound word fua-tulu 'worship' is built by the verb fua 'see' as the modifier and the verb tulu 'give' as the head ; in example (4), the compound word aka'-nama 'crawl' is built by the verb aka' 'say' as the modifier and the verb nama 'creep' as the head. The same process of constructing compound words also presented in example (5) and (6) which are built by combining a verb with a verb.

\section{Noun with Adjective Combination}

This type of compound words in Dawan Language is constructed by combining noun with adjective to form compound words. The result of combining noun with adjective creates new words and carries new meaning automatically is presented in the following table.

Table 6 Noun and Adjective Combination

\begin{tabular}{|c|c|c|c|}
\hline No & $\mathbf{N}+\mathbf{A d j}$ & Compound Word & New Meaning \\
\hline 1. & $\begin{array}{l}\text { ume + kbubu } \\
\text { house' + 'circle' }\end{array}$ & ume-kbubu & 'kitchen' \\
\hline 2. & $\begin{array}{l}\text { atoin + meto } \\
\text { 'people' + 'dry' }\end{array}$ & atoin-meto & 'Timorese' \\
\hline 3. & $\begin{array}{l}\text { neon + tunan } \\
\text { 'day' + 'upon' }\end{array}$ & neon-tunan & 'heaven' \\
\hline 4. & $\begin{array}{l}\text { pah + meto } \\
\text { 'teritory' + 'dry' }\end{array}$ & pah-meto & 'Timor island' \\
\hline 5. & $\begin{array}{l}\text { pah + pinan } \\
\text { 'world' + 'under' }\end{array}$ & pah-pinan & 'world' \\
\hline 6. & $\begin{array}{l}\text { sulat + knino } \\
\text { 'book' + 'clean' }\end{array}$ & sulat-knino & 'bible' \\
\hline 7. & $\begin{array}{l}\text { bia }+ \text { meto } \\
\text { 'cow' }+ \text { 'dry' }\end{array}$ & bia-meto & 'caribou' \\
\hline 8. & $\begin{array}{l}\text { mais + menu } \\
\text { 'salt' + 'bitter' }\end{array}$ & mais-menu & 'salt' \\
\hline
\end{tabular}

These kinds of compound words which derive from combination of noun and adjective is really productive in Dawan language. The compound words (1) - (8) above are formed by combining two different elements of word. One is noun and another is adjective. Each of the word carry its own meaning. But when they are combined, they formed a new nominal category of word and a new meaning. In example (1), the compound word is built by combin- ing the noun ume'house' as the modifier and the adjective $k b u b u$ 'circle' as the head resulting a compound word ume-kbubu 'kitchen'; in example (2), the compound word atoin-meto 'Timorese' is built by the noun atoin 'people' as the modifierand the adjective meto 'dry' as the head; in example (3), the compound word neon -tunan 'heaven' is built by the noen 'day' and the adjective tunan 'upon'; in example (4), the compound word pah-meto 'Timor island' is 
built by the noun pah' 'territory' and the adjective meto 'dry'. The examples (5) (8) also present the same process of constructing compound words which are built by combining a noun with an adjective.

Referring to the structure of compound words as described above, it can be concluded that there are five type of construction of compound nouns based on the component available in Dawan language. The combination of lexical category of those five constructions of compound words as described above are built by combining (1) noun with noun, (2) noun with verb, (3) verb with noun, (4) verb with verb, and (5) noun with adjective. Those five combination of compound words which derive from different type of words category will create a new word category and new meaning.

\section{THE TYPES OF COMPOUND WORD IN DAWAN LANGUAGE}

The previous has described the structure of compound words in Dawan language. This part will try the answer the problem of what types of compound words found in the language. Moreover, the previous part has explained that compound word can be constructed by combining noun with noun, noun with verb, verb with noun, verb with verb, and noun with adjective. Referring to the type of compound words in English as described in the theoretical framework, compound words in Dawan language can also be classified into noun head word, verb head word, and adjective head word. Moreover, noun head word of compound word is structured by combining noun with noun and verb with noun. While, verb head of compound word is constructed by combining noun with verb and verb with verb. And the last, adjective head word of compound word is built by combining noun with adjective. The brief explanation about those types of compound words mentioned above are described in the following.

\section{Noun Head Word/Compound Noun}

As stated previously, this type of compound words are constructed by combining noun with noun and verb with noun. The compound words which are built by combining noun with noun indicate that the head is noun and another noun is a modifier. While, the compound word which is built by combining noun with verb indicate that the head is noun and the verb is modifier The following table (6) exhibits the examples of compound noun or compound words with noun head word.

Table 7 Compound Noun/Noun Head Word

\begin{tabular}{|c|l|c|c|}
\hline NO & \multicolumn{1}{|c|}{ Combination } & Compound Word & New Meaning \\
\hline 1 & $\begin{array}{l}\text { mais }(\mathrm{N})+\text { oni }(\mathrm{N}) \\
\text { 'salt' + 'sweet' }\end{array}$ & mais-oni & 'sugar' \\
\hline 2 & $\begin{array}{l}\text { nui }(\mathrm{N})+\text { nakaf }(\mathrm{N}) \\
\text { 'bone' + 'head' }\end{array}$ & nui-nakaf & 'pull/cranium' \\
\hline 3 & $\begin{array}{l}\text { mat }(\mathrm{N})+\text { lanan }(\mathrm{N}) \\
\text { 'eye' + 'road' }\end{array}$ \\
\hline
\end{tabular}


RETORIKA: Jurnal Ilmu Bahasa, Vol. 2, No.1 April 2016, 12

\begin{tabular}{|c|c|c|c|}
\hline 4 & $\begin{array}{l}\text { uis }(\mathrm{N})+\text { neon }(\mathrm{N}) \\
\text { 'god' + 'day' }\end{array}$ & uis-neon & 'God' \\
\hline 5 & $\begin{array}{l}\text { neno }(\mathrm{N})+\text { anan }(\mathrm{N}) \\
\text { 'day' + 'child' }\end{array}$ & neno-anan & 'yes’' \\
\hline 6 & $\begin{array}{l}\text { fison }(\mathrm{V})+\text { fanu }(\mathrm{N}) \\
\text { 'hit' + 'problem' }\end{array}$ & lison-fanu & 'speak' \\
\hline 7 & $\begin{array}{l}\text { tel }(\mathrm{V})+\text { oe }(\mathrm{N}) \\
\text { 'draw' + 'water' }\end{array}$ & tel-oe & 'dragon fly' \\
\hline 8 & $\begin{array}{l}\text { poni (V) + hauno (N) } \\
\text { 'hang' + 'leaf' }\end{array}$ & poni-hauno & 'propose' \\
\hline 9 & $\begin{array}{l}\text { san }(\mathrm{V})+\text { tuaf }(\mathrm{N}) \\
\text { 'see' }+ \text { 'owned' }\end{array}$ & san-tuaf & 'devil' \\
\hline 10 & $\begin{array}{l}\text { tel + hae } \\
\text { 'brake' + 'foot' }\end{array}$ & tel-hae & 'sandal' \\
\hline
\end{tabular}

The examples of compound words (1) - (10) above are constructed by combining two different elements of word, one word is noun and another word is noun are found in examples (1) - (5), and one word is verb and another word is noun are found in examples (6) - (10). Each of the word carry its own meaning. But when they are combined together, they formed a new nominal category of word and a new meaning. Moreover, examples (1) - (10) exhibit that the head of the compound word is noun.

In example (1) above, the compound word is built by combining the noun aheut 'picker' and the noun susu 'milk' resulting a compound word aheut-susu 'the youngest child'. The head word of the compound word aheut -susu 'the youngest child' is susu 'milk' and the modifier is aheut 'picker'. Example (2), the compound word mais-oni 'sugar' is built by the noun mais 'salt' functioning as the modifier and the noun oni 'sweet' functioning as the head. In example (3), the compound word nuinakaf 'skull' is built by the noun nui 'bone' which functioning as the modifier and the noun nakaf 'head' functioning as theexample (4), the compound word matlanan 'pioneer' is built by the noun mat 'eye' functioning as the modifier and the noun lanan 'road' functioning as the head. And in example (5), the compound word neno-anan 'yes' is built by the noun neno 'day' functioning as the modifier and the noun anan 'child' functioning as the head.

In example (6), the compound word is built by combining the verb fison 'hit' functioning as the modifier and the noun fanu 'problem' functioning as the head resulting a compound word fison-fanu 'speak'. In example (7), the compound word tel-oe'dragon fly' is built by the verb tel 'draw' functioning as the modifier and the noun oe 'water' functioning as the head. In example (8), the compound word poni-haano 'propose' is built by the verb poni 'hang' functioning as the modifier and the noun hauno 'leaf' functioning as the head. In example (9), the compound word san-tuaf 'devil' is built by the verb san 'see' $\backslash$ functioning as the modifier and the noun tuaf 'owned' \ functioning as the head. And in example (10), the compound word tel-hae 'sandal' is built by the verb 
tel 'brake' functioning as the modifier and the noun hae 'foot' \functioning as the head

\section{Verb Head Word}

This type of compound words in Dawan language are built by combining noun with verb and verb with verb. The compound word which is built by combin- ing noun with verb indicated that the head is verb and the noun has the function as a modifier. While, the compound words which are built by combining verb with verb indicated that the head is verb and the other verb is as modifier. The following table (7) presents the examples of compound words with verb head word.

Table 8 Compound Verb/Verb Head

\begin{tabular}{|c|c|c|c|}
\hline No & Combination & Compound Word & New Meaning \\
\hline 1. & $\begin{array}{l}\operatorname{lan}(\mathrm{N})+\text { lefit }(\mathrm{V}) \\
\text { 'road' + 'cut' }\end{array}$ & lan-lefit & 'shortcut' \\
\hline 2. & $\begin{array}{l}\text { bife }(\mathrm{N}) \text { + anaot }(\mathrm{V}) \\
\text { 'woman' + 'work' }\end{array}$ & bife-anaot & 'prostitute' \\
\hline 3. & $\begin{array}{l}\text { ume }(\mathrm{N})+\text { hana }(\mathrm{V}) \\
\text { 'house' + 'cook' }\end{array}$ & ume-hana & 'kitchen' \\
\hline 4. & $\begin{array}{l}\text { oe }(\mathrm{N})+\text { hani }(\mathrm{V}) \\
\text { 'water' + 'dig' }\end{array}$ & ne-hani & 'well' \\
\hline 5. & $\begin{array}{l}\text { pete }(\mathrm{V})+\text { kloe }(\mathrm{V}) \\
\text { 'dumpen' + 'cook' }\end{array}$ & pete-kloe & 'soaking wet' \\
\hline 6. & $\begin{array}{l}\operatorname{tun}(\mathrm{V})+\operatorname{tauk}(\mathrm{V}) \\
\text { 'burn'+ 'watch' }\end{array}$ & tun-tauk & 'watch over' \\
\hline 7. & $\begin{array}{l}\text { fua }(\mathrm{V})+\text { tulu }(\mathrm{V}) \\
\text { 'see' + 'give' }\end{array}$ & fua-tulu & 'worship' \\
\hline 8. & $\begin{array}{l}\text { aka' (V) + nama (V) } \\
\text { 'say' + 'creep' }\end{array}$ & aka-nama & 'crawl' \\
\hline
\end{tabular}

Examples (1) - (8) exhibited that the head of the compound word is verb. The compound word in example (1) is built by combining the noun lan 'road' functioning as the modifier and the verb lefit 'cut' functioning as the head with resulting a compound word lan-lefit'shortcut'. The compound word bife-anaot'prostitute' in example (2) is built by the noun bife 'woman' functioning as the modifier and the verb anaot 'work' functioning as the head. In example (3), the compound word ume-hana 'kitchen' is built by the noun ume 'house' functioning as the modifier and the verb hana 'cook' functioning as the head. In example (4), the compound word oe-hani 'well' is built by the noun oe 'water' functioning as the modifier and the verb hani 'dig' functioning as the head.

The compound word in example (15), is built by combining the verb pete'dumpen' functioning as the modifier and the verb kloe 'cook' functioning as the head with resulting a compound word petekloe 'soaking wet'. The compound word tun-tauk 'watch over' in example (16) is built by the verb tun 'burn' functioning as the modifier and the verb tauk 'watch' functioning as the head. In example (17), the compound word fua-tulu 'worship' is built by the verb fua 'see' functioning as the modifier and the verb tulu 'give' func- 
tioning as the head. And in example (18), the compound word aka'-nama 'crawl' is built by the verb aka' 'say' functioning as the modifier and the verb nama 'creep' functioning as the modifier.

\section{Adjective Head Word}

This type of compound words in
Dawan language are constructed by combining noun with adjective. The compound word which is built by combining noun with adjective indicated that the head is adjective and the noun has the function as a modifier. Look at the following table (8) which exhibits the examples of compound words with adjective head word.

Table 8 Adjective Head Word

\begin{tabular}{|c|l|c|c|}
\hline No & \multicolumn{1}{|c|}{ Combination } & Compound Word & New Meaning \\
\hline 1 & $\begin{array}{l}\text { Ume (N) + kbubu (Adj) } \\
\text { 'house' + 'circle' }\end{array}$ & ume-kbubu & 'kitchen' \\
\hline 2 & $\begin{array}{l}\text { Atoin (N) + meto (Adj) } \\
\text { 'people' + 'dry' }\end{array}$ & neon-tunan & 'Timorese' \\
\hline 3 & $\begin{array}{l}\text { Neon (N) + tunan (Adj) } \\
\text { 'day' + 'upon' }\end{array}$ & $\begin{array}{l}\text { pah-meto } \\
\text { 'teritory' + 'dry' }\end{array}$ & pah-pinan \\
\hline 5 & $\begin{array}{l}\text { pah (N) + pinan (Adj) } \\
\text { 'world'+ 'under' }\end{array}$ & 'world' \\
\hline
\end{tabular}

The examples (1) - (5) in the table (8) above indicated that the compound words are formed by combining two different elements of word, one word is noun and another word is adjective. In examples (1) $-(5)$, one word is noun and another word is adjective. Moreover, examples (1) - (5) indicated that the head of the compound word is adjective.

The compound word in example (1) is built by combining the noun umev 'house' functioning as the modifier and the adjective $k b u b u$ 'circle' functioning as the head resulting a compound word ume$k b u b u$ 'kitchen'. In example (2), the compound word atoin-meto 'Timorese' is built by the noun atoin 'people' functioning as the modifier and the adjective meto 'dry' functioning as the head. In example (3), the compound word neon -tunan 'heaven' is built by the noen 'day' which functioning as the modifier and the adjective tunan 'upon' functioning as the head. The compound word pah-meto 'Timor island' in example (4) is built by the noun pah' 'territory' functioning as the modifier and the adjective meto 'dry' functioning as the head. And the compound word pah-pinan 'world' in example (5) is built by the noun pah' 'world' functioning as the modifier and the adjective pinan 'under' functioning as the head.

\section{CONCLUSION}

Based on the data analysis on the structure and the types of compound words, it was found that the structure of compound words in Dawan language are constructed 
by combining two different words. They are built by combining noun $(\mathrm{N})$ with noun $(\mathrm{N})$, for instance mais-oni 'sugar' which is built by the noun mais 'salt' and the noun oni 'sweet'; noun $(\mathrm{N})$ with verb (V), for instance bife-anaot 'prostitute' which is built by the noun bife 'woman' and the verb anaot 'work'; verb (V) with noun $(\mathrm{N})$, for instance poni-haano 'propose' which is built by the verb poni 'hang' and the noun hauno 'leaf'; verb (V) with verb (V), for instance fua-tulu 'worship' which is built by the verb fua 'see' and the verb tulu 'give'; and noun $(\mathrm{N})$ with adjective (Adj), for instance ume-kbubu 'kitchen' which is built by the noun ume 'house' and the adjective $k b u b u$ 'circle'. Referring to the theory of types of compound words, the types of compound words found in Dawan language can be further classified into compound noun or noun head word, compound verb or verb head word, and compound adjective or adjective head word. Moreover, compound noun are constructed by combining noun with noun and verb with noun. While, compound verb are constructed by combining noun with verb and verb with verb. And the last, compound adjective are only built by combining noun with adjective in Dawan language.

\section{ACKNOWLEDGEMENTS}

Thanks to peer reviewer for the critic and suggestion to make this article better.
Morphology. Edinburgh: Edinburgh University Press.

Booij, Geert. 2005. The Grammar of Words. An Introduction to Linguistic Morphology. Second Edition. Oxford University Press

Budiarta, I Wayan. 2009. Aliansi Gramatikal Bahasa Dawan (Kajian Tipologi Bahasa) (tesis). Denpasar: Program Pascasarjana Universitas Udayana.

Carstairs-Mccarthy, Andrew, 2002. An Introduction to English Morphology: Edinburgh: Edinburgh University Press

Chaer, Abdul. 1996. Linguistik Umum. Jakarta. PT. Rineka Cipta.

Francis Katamba. 1993. Morphology. Modern Linguistics. London: Macmillan Press Ltd

Fromkin and Rodman.1996. An Introduction to Language. Second Edition. Hartcourt Brase Javanovich College Publisher.

Hasplemath, Martin. 2002. Understanding Morphology, New York Oxford University Press Inc.

Lieber, Rochelle. 2009. Introducing Morphology. New York: Cambridge University Press

Sanga, Felysianus. 1991a. Perbandingan Struktur Bahasa Indonesia dengan Bahasa Dawan. Kupang :Proyek Penelitian Bahasa dan Sastra Indonesia dan Daerah NTT.

Sanga, Felysianus. 1991b. Kamus Dwibahasa Indonesia-Dawan. Kupang: Proyek Penelitian Bahasa dan Sastra Indonesia dari Daerah NTT.

Sudaryanto, 1993. Metode dan Aneka Teknik Analisis Bahasa. Yogyakarta: Duta Wacana University Press.

Tarno dkk. 1992. Tata Bahasa Dawan. Jakarta: Pusat Pembinaan dan Pengembangan Bahasa

\section{BIBLIOGRAPHY}

Bauer Laurie. 1988. Introducing Linguistics 